\title{
Differences in Virulence and Sporulation of Phytophthora kernoviae Isolates Originating From Two Distinct Geographical Regions
}

\author{
T. L. Widmer, Research Plant Pathologist, United States Department of Agriculture-Agricultural Research Service, Foreign Disease Weed \\ Science Research Unit, Fort Detrick, MD, 21702
}

\begin{abstract}
Widmer, T. L. 2015. Differences in virulence and sporulation of Phytophthora kernoviae isolates originating from two distinct geographical regions. Plant Dis. 99:460-466.

Phytophthora kernoviae has only been isolated from the United Kingdom and New Zealand. To understand what differences may exist between isolates from these two distinct geographical regions, virulence studies on three host plants and sporulation on host leaves were conducted on select isolates. Three host plant species (Rhododendron ponticum, Magnolia stellata, and Annona cherimola) were inoculated individually with sporangia of six different isolates from each geographical region. Results showed an overall higher virulence on all three hosts

from isolates originating from the United Kingdom. After inoculation, $P$. kernoviae sporangia and oospore formation on different host leaves were observed and compared with $P$. cactorum and $P$. syringae. Results were host dependent, with $P$. kernoviae producing generally similar or higher amounts of both propagules compared with the other U.S. indigenous species. These results have implications for regulatory agencies and scientists who are interested in preventing its entrance into the United States and learning more about its potential spread.
\end{abstract}

Movement and introductions of crops and plants into a new area has the potential to both move exotic pathogens into that area and expose new hosts to previously noncharacterized indigenous plant pathogens. The consequences of these new interactions are often unknown but have had serious implications in the past, including diseases caused by the genus Phytophthora $(3,26)$. Some Phytophthora spp., such as Phytophthora infestans, have a very limited host range while others, such as $P$. ramorum, have a very broad host range. When new species or diseases are discovered, it is important to investigate the host range and the role that hosts may have on the spread and persistence. Some hosts of specific Phytophthora spp. are reported to be "dead-end" hosts, meaning they become infected but do not support sporulation (33) while other hosts are known to drive epidemics (7).

Phytophthora kernoviae Brasier, Beales, \& S. A. Kirk was first isolated in 2003 in the United Kingdom on bleeding cankers of Fagus sylvatica and foliar lesions of Rhododendron ponticum $\mathrm{L}$ (5). It is believed to have been introduced into the United Kingdom

Corresponding author: T. L. Widmer, E-mail: Tim.Widmer@ars.usda.gov

The use of trade, firm, or corporation names in this article is for the information and convenience of the reader. Such use does not constitute an official endorsement of approval by the United States Department of Agriculture (USDA) Agricultural Research Service, NAL, or BIC of any product or service to the exclusion of others that may be suitable.

The USDA prohibits discrimination in all its programs and activities on the basis of race, color, national origin, age, disability, and, where applicable, sex, marital status, familial status, parental status, religion, sexual orientation, genetic information, political beliefs, reprisal, or because all or a part of an individual's income is derived from any public assistance program. (Not all prohibited bases apply to all programs.) Persons with disabilities who require alternative means for communication of program information (Braille, large print, audiotape, etc.) should contact USDA's TARGET Center at (202) 720-2600 (voice and TDD). To file a complaint of discrimination write to USDA, Director, Office of Civil Rights, 1400 Independence Avenue, SW, Washington, DC 20250-9410 or call (800) 795-3272 (voice) or (202) 7206382 (TDD). USDA is an equal opportunity provider and employer.

Accepted for publication 31 October 2014.

http://dx.doi.org/10.1094/PDIS-09-14-0957-RE

This article is in the public domain and not copyrightable. It may be freely reprinted with customary crediting of the source. The American Phytopathological Society, 2015. within the past 10 to 20 years based upon its distribution, spread, and genetic homogeneity $(2,10)$. It is hypothesized to have been first reported in New Zealand, where a previously reported unidentified Phytophthora sp. isolate, originally collected in the 1950s, was morphologically similar to what is now identified as P. kernoviae (34). However, no conclusions were drawn on its origin in this region. $P$. kernoviae has known hosts across a range of plant families and there is concern that this species will enter the United States, causing similar problems to those associated with $P$. ramorum. In response to this threat, a recovery plan was developed (1).

Determining the center of origin of a plant pathogen is important because it is critical to understanding the mechanisms of global emergence (20), which assists in disease prevention and control (50). For some pathogens, such as $P$. ramorum, the center of origin is not known despite repeated attempts to locate it. When this information is not known, it becomes important to test and compare isolates from distinct geographical locations when possible. These comparisons of different isolates become important in understanding the potential threat a pathogen may pose if introduced into another new area, and where the most serious threat may originate.

Observations on phenotypic differences between isolates - specifically, aggressiveness or virulence-are important to regulatory agencies and researchers who are involved in monitoring programs and conducting host range studies. Previous studies involving Phytophthora spp. have noted differences in virulence among isolates $(14,21,27)$. Extensive host range studies with $P$. ramorum have been conducted using a wide variety of isolates $(4,15,30,42,43,47)$. However, there have been very few studies on the host susceptibility to $P$. kernoviae $(13,18)$, and those studies have used very few isolates collected from a similar habitat in close proximity.

Another piece of information important to learning about a new threat is understanding the epidemiology of the pathogen as much as possible to help prevent or manage its spread. Of particular interest to growers and ecosystem managers is the short-distance spread. Phytophthora spp. are well adapted to spread quickly from plant to plant when conditions are favorable. Many species produce sporangia that can detach from their mycelium and be carried by wind or rain splash (16). In addition, government regulatory agencies are interested in the production of long-term survival structures (i.e., chlamydospores and oospores) that are important in long-distance movement and overwintering. Human activity is known to play an instrumental role in long-distance dispersal of plant pathogens. For example, both $P$. ramorum and $P$. kernoviae have been found on hikers' boots in infested areas and implicated in the spread of this pathogen $(8,9,44)$, beyond the distances expected for aerial dispersal. 
The goals of this study were to investigate differences in virulence on selected hosts of isolates from two distinct geographical origins and study the sporulation potential of $P$. kernoviae on selected hosts, comparing this with indigenous Phytophthora spp. that are known to cause problems in the United States. For this study, virulence is being defined as "the measurable degree of damage" $(37,41)$. Results from this study will help to distinguish any differences between those isolates originating from the United Kingdom and New Zealand. This will help to guide initial isolate selection for host range tests and demonstrate different host reactions to different isolates, and could offer clues to the origin of $P$. kernoviae. Portions of this study were reported earlier (48).

\section{Materials and Methods}

Isolates and inoculum production. Information on the Phytophthora spp. isolates used in this study is listed in Table 1. All P. kernoviae isolates were obtained directly from their country of origin. The two other species used in this study, P. cactorum (Lebert \& Cohn) J. Schröt and P. syringae (Kleb.) Kleb., were chosen because they both are considered indigenous to the United States, are homothallic like $P$. kernoviae, and are known to cause disease on rhododendron plants in commercial nurseries. All isolates were maintained on clarified V8 agar at $20^{\circ} \mathrm{C}$ and routinely reisolated from infected plant material to maintain pathogenicity. Clarified V8 agar was prepared by first clarifying $350 \mathrm{ml}$ of V8 juice (Campbell Soup Co., Camden, NJ) by stirring in $5 \mathrm{~g}$ of $\mathrm{CaCO}_{3}$ for approximately $20 \mathrm{~min}$ and centrifuging for $20 \mathrm{~min}$ at $3,210 \times \mathrm{g}$. The supernatant was carefully decanted into a flask containing $18 \mathrm{~g}$ per liter of agar and diluted 1:4 with deionized water prior to autoclaving for $20 \mathrm{~min}$ at $121^{\circ} \mathrm{C}, 1.4$ bars.

Cultures of the Phytophthora spp. were grown according to the method described by Widmer (45) for sporangia production. Three plugs ( $5 \mathrm{~mm}$ diameter) from the edge of an actively growing culture of each isolate were transferred to $13 \mathrm{ml}$ of $10 \%$ clarified V8 broth in petri plates (100 $\mathrm{mm}$ diameter). The cultures were incubated at $20^{\circ} \mathrm{C}$ under continuous light $(3,000$ lux). After 5 days, the sporangia were separated from the mycelium by vigorously shaking the cultures and filtering through four layers of sterile cheesecloth. The sporangia concentration per milliliter was calculated by averaging the number of sporangia in three $20-\mu$ l drops and multiplying by 50 . If necessary, the original sporangia suspension was diluted 10 -fold in $10 \%$ V8 broth before counting.

Zoospores of the Phytophthora spp. were produced by inducing release from the sporangia as described above. Once sporangia were confirmed after 5 days, the sporangia suspension was placed at $4^{\circ} \mathrm{C}$, removed after $30 \mathrm{~min}$, and placed on the bench at room temperature for zoospore release. Zoospore concentration was determined by diluting the zoospore suspension in water, vortexing to induce encystment, and counting on a hemacytometer.

Plant host species. $R$. ponticum (original host for many P. kernoviae isolates in the United Kingdom), Rhododendron 'Cunningham's White', Liriodendron tulipifera L., and Magnolia stellata (Siebold \& Zucc.) Maxim. (hosts not reported under natural conditions) were originally purchased from a commercial nursery. Additional plants of these species were propagated as needed by rooted cuttings. All plants were maintained in the greenhouse with drip irrigation and were at least 1 year old before use. Cherimoya (Annona cherimola Mill.) 'White' plants (host reported in New Zealand) were propagated from seed collected from mature fruit supplied by Pinehill Ranch (Carpinteria, CA). Kalmia latifolia L. (host reported for $P$. syringae) leaves were collected from plants in a natural ecosystem the day before the experiment and kept moist at $4{ }^{\circ} \mathrm{C}$ prior to use. $L$. tulipifera and $K$. latifolia were chosen because at least one of them was a reported host for $P$. syringae or $P$. cactorum (29).

Whole-plant inoculations. Sporangia of $P$. kernoviae isolates 2436, 2565, 2577, 2605, 2618, 2650, NZFS2646, NZFS2692, NZFS2696, NZFS2702, NZFS2881, and NZFS2882 were produced as described above. For each replication of each species, five plants, uniform in age and leaf number, were selected and sprayed with $20 \mathrm{ml}$ of 3,000 sporangia/ml. The plants were placed in a dew chamber with constant dew at $20^{\circ} \mathrm{C}$ in a completely randomized design. After 7 days, the plants were removed and, for $R$. ponticum and $M$. stellata, all leaves were detached and immediately scanned with an HP Scanjet 5500C model flatbed scanner (HewlettPackard; Palo Alto, CA). In addition, for $R$. ponticum, the stems were grouped together based on a 0 -to-5 scale depending upon lesion severity on the stem (Fig. 1). Stem lesions were not evident for M. stellata or A. cherimola; therefore, stem ratings were not done for these species. For A. cherimola, some leaves had fallen prior to removal from the dew chamber. These fallen leaves were counted and immediately scanned. The A. cherimola plants were placed on a greenhouse bench for 1 week and any leaves that detached during that time were immediately recorded and scanned. After this time period, the remaining leaves were detached and scanned. Using the scanned images, the percent necrosis of each leaf was determined using ASSESS software (version 2.0; American Phytopathological Society, St. Paul, MN). The experiment was conducted three times for each plant species.

Due to the low necrosis observed on the A. cherimola whole plants, another test was set up using detached leaves of this host

Table 1. Characteristics of Phytophthora spp. isolates used in this study

\begin{tabular}{llll}
\hline Species & Designation & Original host material & Region of collection \\
\hline$P$. kernoviae & NZFS2646 & Annona cherimola & Northland, New Zealand \\
$P$. kernoviae & NZFS2692 & A. cherimola & Northland, New Zealand \\
$P$. kernoviae & NZFS2696 & Soil & Bay of Plenty, New Zealand \\
$P$. kernoviae & NZFS2702 & Soil & Taupo, New Zealand \\
$P$. kernoviae & NZFS2881 & Soil & Auckland, New Zealand \\
$P$. kernoviae & NZFS 2882 & Soil & Auckland, New Zealand \\
$P$. kernoviae & ICMP 15082 & Soil & Trounson Kauri Park, New Zealand \\
$P$. kernoviae & ICMP 14761 & A. cherimola & Northland, New Zealand \\
$P$. kernoviae & 2605 & Rhododendron ponticum & Kent, England \\
$P$. kernoviae & 2618 & R. ponticum & Republic of Ireland \\
$P$. kernoviae & 2650 & Drimys winteri & Isle of Arran, Scotland \\
$P$. kernoviae & 2565 & Vaccinium myrtilus & United Kingdom \\
$P$. kernoviae & 2577 & Lomatia myricoides & United Kingdom \\
$P$. kernoviae & R. ponticum & Cheshire, England \\
$P$. kernoviae & 2436 & R. ponticum & Cornwall, United Kingdom \\
$P$. kernoviae & CSL 2378 & R. ponticum & Cornwall, United Kingdom \\
$P$. cactorum & CSL 2286 & Rhododendron sp. & North Carolina, United States \\
$P$. cactorum & Pcac1 & Pseudotsuga menziesii & Washington, United States \\
$P$. syringae & 311 & Kalmia latifolia & Oregon, United States \\
$P$. syringae & 468 & K. latifolia & Oregon, United States \\
\hline
\end{tabular}


plant. Six leaves from cherimoya plants were detached for each isolate and placed on plastic mesh screens on a moist paper towel in individual plastic petri plates. A small wound point on the abaxial side of the leaf was made with a needle. A 3-mm-diameter plug of the $P$. kernoviae isolate was taken from the edge of an actively growing culture on V8 agar and placed, mycelium side down, over the wound site. A control was also included using the same procedure above, except using only a plug of V8 agar. The plug was moistened with sterile water and the petri plate was covered and placed in the dark at $20^{\circ} \mathrm{C}$. After 1 week, the detached leaves were scanned, abaxial side down, and the total area of necrosis that developed on each leaf was measured using ASSESS software. The experiment was conducted three times for each of the 12 P. kernoviae isolates listed above.

Sporangia and oospore production on leaf disks. Sporangia of P. kernoviae isolates ICMP 15082, ICMP 14761, CSL 2378, and CSL 2286; $P$. cactorum isolates Pcac1 and 311 ; and $P$. syringae isolates 468 and 469 were produced as described above. The sporangia were induced to release zoospores as described above. At least 10 leaves were collected for each of the host plants (Rhododendron Cunningham's White, L. tulipifera, M. stellata, and K. latifolia) and surface sterilized by exposure to $70 \%$ ethanol. Leaf disks $(11 \mathrm{~mm}$ diameter) were cut from the leaves and placed abaxial side up on a mesh screen on a moist paper towel in a petri plate just prior to inoculation. To determine sporangia production on the leaf surface, 7,500 zoospores were pipetted onto the leaf disk surface that contained a drop of sterilized water, if necessary, so that the final volume of liquid was $50 \mu \mathrm{l}$. Five leaf disks of each plant species were used for each isolate for each replication. The petri plates were closed with the lid (but not sealed) and placed in a $20^{\circ} \mathrm{C}$ incubator in the dark. The paper towel was kept moist by carefully adding water, if necessary.

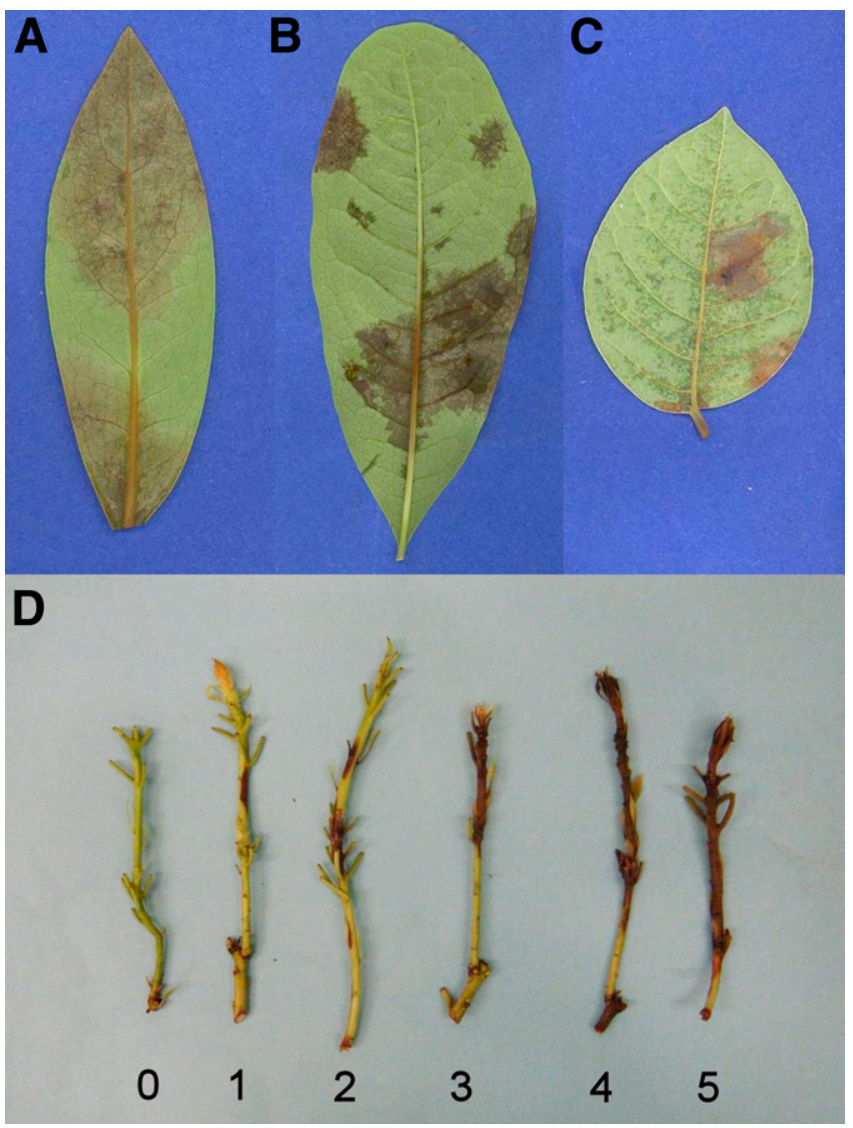

Fig. 1. Leaf necrosis symptoms on A, Rhododendron ponticum; $\mathbf{B}$, Magnolia stellate; and $\mathbf{C}$, Annona cherimola leaves and $\mathbf{D}$, rating scale on $R$. ponticum stems after artificial inoculation with Phytophthora kernoviae sporangia. Stem rating of $0=$ no visible lesion; $1=$ one lesion $(<1.0 \mathrm{~cm}$ in length); $2=$ two or more lesions, noncoalesced $(<1.0 \mathrm{~cm}$ in length); $3=$ coalesced lesion, covering $\leq 50 \%$ of the stem; 4 = coalesced lesion, covering 51 to $90 \%$ of the stem; and $5=$ coalesced lesion, covering $>90 \%$ of the stem.
After 7 days, the leaf disks were transferred individually to $1 \mathrm{ml}$ of water in an Eppendorf tube. The tubes were vortexed to release the sporangia and the concentration of sporangia per $100 \mathrm{~mm}^{2}$ of disk area was calculated. Because $P$. syringae sporangia are noncaducous, the leaf surface was scraped additionally with a plastic pestle directly in the Eppendorf tube to dislodge the sporangia. The leaf disks were then removed, surface sterilized for $20 \mathrm{~s}$ in $70 \% \mathrm{EtOH}$, rinsed two times in sterile water, and plated on PARPH + V8 selective medium. Infection was recorded as positive if the inoculated Phytophthora sp. mycelium was identified growing from the leaf disk into the medium. The experiment was conducted a total of three times for each isolate on each plant species.

For oospore production, inoculation techniques were similar to those described above for sporangia production, except the leaf disks were stored for 2 weeks in a $20^{\circ} \mathrm{C}$ incubator in the dark after inoculation. Afterward, the leaf disks were removed and submerged in Carnoy's solution (three parts ethanol to one part glacial acetic acid) for 7 to 10 days to clear the tissue, then further cleared with $10 \%$ $\mathrm{KOH}$. After the disks were cleared sufficiently, the $\mathrm{KOH}$ was removed and replaced with $0.05 \%$ aniline blue in lactic acid overnight to stain the oospores. The aniline blue was removed from the tubes and replaced with $1 \mathrm{ml}$ of water. The disks were ground with a plastic pestle and the suspension was diluted 1:10 in water, if necessary, before counting the oospores in a $25-\mu 1$ aliquot. The experiment was conducted a total of three times for each isolate on each plant species.

Statistical data. Data of the scanned leaves for all plant species tested after whole-plant inoculations and percentage of detached cherimoya leaves failed a normality test based on the Shapiro-Wilk test $(P>0.05)$ and were arcsine square root transformed prior to analyses. The transformed values were subjected to analysis of variance (ANOVA) and any regional effects were determined by subjecting the means of the transformed values to least square means analysis with the pdiff option using Proc MIXED in SAS for Windows (version 9.2; SAS Institute, Cary, NC). Data for the necrotic area of the detached cherimoya leaves were analyzed by ANOVA using Proc GLM in SAS for Windows. Data of the $R$. ponticum stem rating and percentage of leaf necrosis were analyzed using the regression procedure of Minitab (release 16; Minitab, Inc., University Park, PA). After subjection to ANOVA, the means of the number of sporangia or oospores of the different Phytophthora spp. produced on different plant species were subjected to Tukey's studentized test using Proc GLM in SAS for Windows (version 9.2).

\section{Results}

Whole-plant Inoculations. Symptoms on R. ponticum, M. stellata, and $A$. cherimola leaves after sporangia inoculation were generally nondescript necrotic lesions (Fig. 1). Differences among isolates within a geographical region were only observed for the New Zealand isolates on $R$. ponticum $(P=0.0076)$. All other isolates within a region on a specific host were not significantly different in terms of the amount of necrosis on the host. When the isolates were combined within their geographical origin, those isolates from the United Kingdom resulted in a significantly higher percentage of leaf necrotic area for $R$. ponticum $(t$ value $=-3.67 ; P=0.0008), M$. stellata $(t$ value $=$ $-4.60 ; P<0.0001$ ), and $A$. cherimola ( $t$ value $=-2.40 ; P=0.0221)$ compared with those isolates from New Zealand. Not surprisingly, $R$. ponticum showed the highest susceptibility but also the most variability among the isolates (Fig. 2A). There was also a difference ( $t$ value $=-4.17 ; P=0.0002$ ) in the disease rating of $R$. ponticum stems among the two different geographical origins (Fig. 2A). There was a correlation between the percentage of leaf necrosis and stem rating $\left(r^{2}=0.49 ; P<0.0001\right)$. No stem lesions were observed on the M. stellata or A. cherimola plants. Less necrosis was visible on the M. stellata leaves (Fig. 2B) and very little necrosis occurred on A. cherimola (Fig. 2C), a plant from which two of the New Zealand isolates (NZFS2646 and NZFS2692) were isolated. However, all isolates on all hosts had a significantly higher $(P \leq 0.05)$ percentage of leaf necrotic area than the noninoculated controls (data not shown). 
Inoculated, detached cherimoya leaves showed no difference among any of the isolates or between any isolates and the noninoculated control $(P=0.92)$. The average necrotic area of the inoculated, detached leaves ranged from 0.0 to $20.5 \mathrm{~cm}^{2}\left(\right.$ mean $\left.=0.88 \pm 0.4 \mathrm{~cm}^{2}\right)$, with the control averaging $0.07 \pm 0.02 \mathrm{~cm}^{2}$. In whole-plant inoculations, there was no difference in the percentage of cherimoya leaves dropped, which ranged from 12 to $34 \%$ (mean $=20 \%$ ) as a response to inoculation among the isolates $(P=0.497)$, but there was a difference in leaf drop comparing the noninoculated controls to those plants inoculated with the U.K. isolates $(P=0.009)$ and New Zealand isolates $(P=0.022)$. It was noted that inoculated whole plants of $R$. ponticum and $M$. stellata did not drop their leaves.

Sporangia and oospore production on leaf disks. There was no statistical difference among the two P. kernoviae isolates from the United Kingdom or among the two from New Zealand; therefore, the data for each separate geographical location were combined. For sporangial production, the $P$. kernoviae isolates always produced the highest amount regardless of the host, although they were not always statistically different than the other species (Table 2). Between the $P$. kernoviae isolates, those originating from the United Kingdom produced significantly higher numbers of sporangia on the hosts M. stellata, K. latifiolia, and L. tulipifera. P. syringae had the lowest production of sporangia on the leaf disks. When plated on the selective medium, all inoculated leaf disks confirmed infection. However, some disks did not have obvious necrotic symptoms and were categorized as asymptomatic.

$P$. cactorum consistently produced the most oospores in tissue (Table 3). There was only a significant difference between the United Kingdom and New Zealand isolates when Rhododendron Cunningham's White was the host plant. In this study, L. tulipifera supported the highest number of oospores for $P$. kernoviae regardless of the isolate origin. Overall, $K$. latifolia supported the fewest oospores for all three species tested.

\section{Discussion}

In terms of virulence, phenotypic differences were observed between $P$. kernoviae isolates originating from the United Kingdom and those from New Zealand. The origins of $P$. kernoviae are unknown but it is believed to be a rather recent invasion into the United Kingdom based upon its distribution, spread, and genetic homogeneity (2). Although no definite answer can be made from the data in this study on whether or not P. kernoviae originates from New Zealand, the evidence of more virulent isolates observed in this study and the genetic homogeneity observed in an unpublished study by Beales and Webb (http://www.fera.defra.gov.uk/plants/plantHealth/pestsDiseases/ phytophthora/documents/phytophthoraKernoviaeSequencing.pdf) within the U.K. isolates does confirm that it likely did not originate from the United Kingdom. Isolates of an introduced clonal line of $P$. infestans were found to be more aggressive than original lineages $(19,32)$. When $P$. capsici isolates were grouped by continent of origin, differences in mean lesion diameter were observed (21). Yin et al. (49) found no correlation between aggressiveness of $P$. capsici isolates and their host origin or geographical location of isolation. However, in that study, all isolates were collected from different counties within the state of Georgia, which may not have been diverse or geographically distinct enough to notice any differences.

Although $P$. kernoviae has a fairly wide host range $(10,17)$, an important host within the United Kingdom appears to be $R$. ponticum $(6,18)$. $R$. ponticum was introduced into New Zealand as an ornamental but has since been listed as a pest plant. The primary distribution of $R$. ponticum has been limited mainly on the north island, with several locations on the south island (http://www.nzflora.info/factsheet/ Weed/Rhododendron_ponticum.html). All locations of the P. kernoviae isolates used in this study were from the north island but it is not known whether any of these locations actually overlap with the known distribution of $R$. ponticum. However, results from this study show that, if their habitats would overlap and conditions for infections (e.g., temperature, humidity, and so on) permit it, infection and subsequent sporulation could be rather high, as has been observed in the United Kingdom. This could lead to a more widespread epidemic and more aggressive strains. A study by Spiglazova et al. (39) showed that the aggressiveness of $P$. infestans increased as a result of repeated reproduction on potato cultivars. In addition, Grönberg et al. (23) showed that alternate weed hosts increased $P$. infestans aggressiveness on potato. Although limited in the isolates tested, there was no difference in virulence between the two New Zealand isolates originating from $A$. cherimola tissue and those isolated from soil. Overall, the percentage of leaf necrosis was higher on the cherimoya leaves from the detached leaf experiment than those from the whole-plant inoculations. This difference may be largely explained by the drying out of some of the detached leaves, which was difficult to distinguish in the ASSESS program between necrosis caused by $P$. kernoviae. This is evident as what appears to be a relatively high necrotic area in the noninoculated controls. Control leaves did not result in recovery of $P$. kernoviae when plated on the selective medium, whereas $P$. kernoviae was recovered from the inoculated leaves. Another possibility is the difference in inoculation

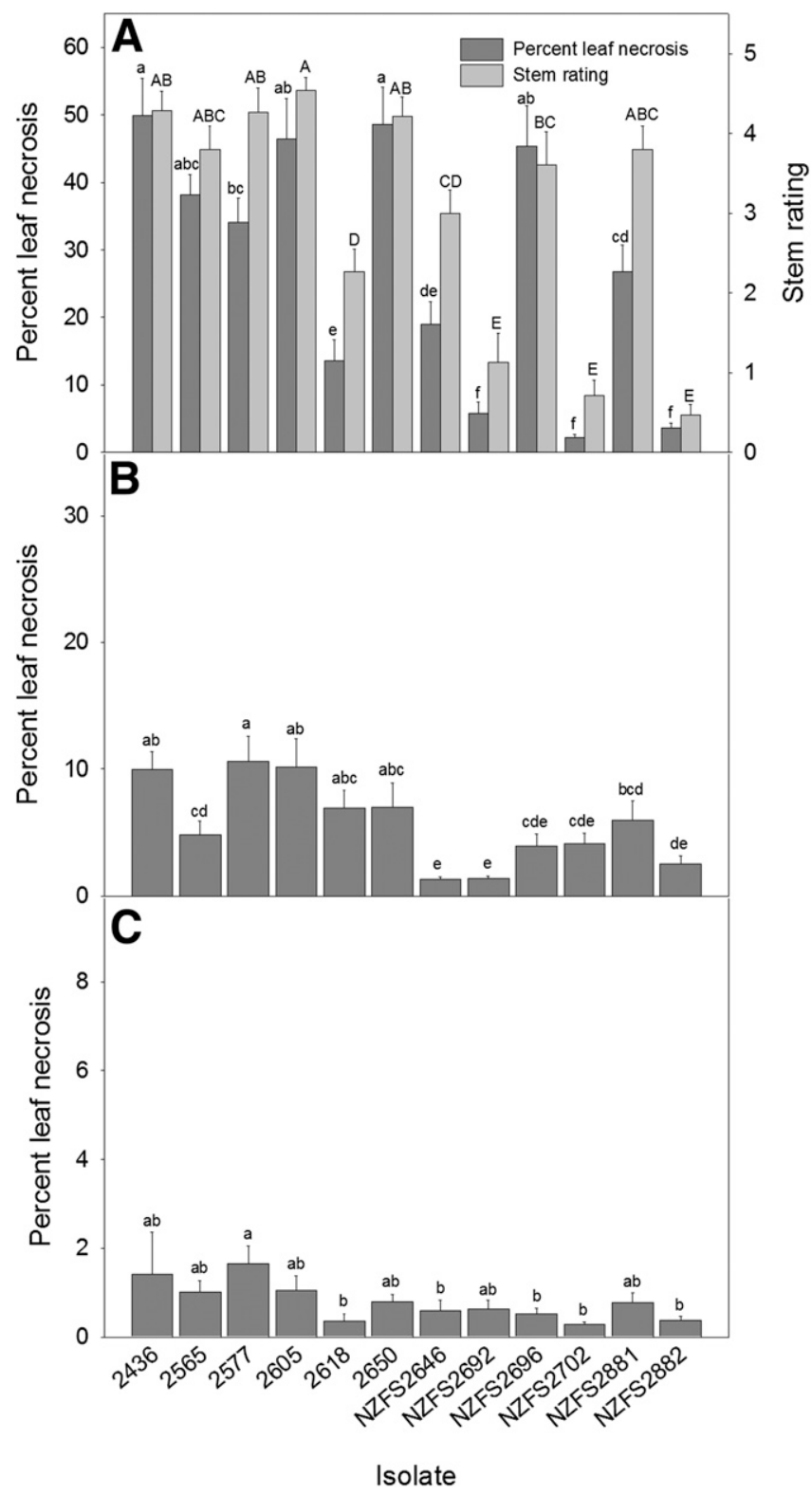

Fig. 2. Percent leaf necrotic area and stem rating of $\mathbf{A}$, Rhododendron ponticum and percent leaf necrotic areas of B, Magnolia stellata and C, Annona cherimola at 7 days after inoculation with different isolates of Phytophthora kernoviae sporangia. Error bars represent standard error of the mean. Isolates labeled with similar letters did not differ significantly $(P>0.05)$ in the percent leaf necrotic area (lowercase) after arcsine square root transformation and stem rating (uppercase) by least square means analysis. 
techniques. The detached leaves were first wounded before exposure to the pathogen. Denman et al. (11) found that wounded leaves generally had higher necrosis than nonwounded leaves after inoculation with $P$. ramorum.

As noted in the results, inoculated cherimoya plants were more likely to drop their leaves than noninoculated plants. This would indicate a host response to inoculation. Leaf drop has been shown to be a response to infection by other pathogens, including $P$. ramorum $(36,38)$. Shishkoff (38) was able to recover $P$. ramorum on defoliated camellia leaves after inoculation even though they were asymptomatic. In contrast, $P$. kernoviae was not isolated from any of the defoliated cherimoya leaves that were asymptomatic but could be isolated from symptomatic tissue that had defoliated. Because only a representative sample of the leaves was plated, it cannot be said with certainty whether all asymptomatic defoliated leaves were not infected. Defoliation of infected leaves is important because this is an avenue for propagules to infest surrounding soil and infect susceptible roots. $P$. kernoviae oospores have been observed in infected leaf tissue (personal observation) and in asymptomatic Umbellularia californica roots (18). Because $P$. kernoviae is not known to produce chlamydospores, the propagule most likely involved in long-distance dispersal would be oospores. This study showed that $P$. kernoviae oospores were readily formed in the detached leaves of the four host plants tested, although very few $P$. kernoviae oospores were detected in the $K$. latifolia leaves (Table 3 ). K. latifolia was specifically chosen as a test plant because of the perceived similarities between $P$. kernoviae and $P$. ramorum. $K$. latifolia has been postulated to be a potentially important host in the eastern United States for $P$. ramorum should it become established there (42). The viability of the oospores was not tested in this study but their appearance was similar to that observed in cultures in a previous test (46). Oospores in fallen leaves were found to be important in the survival and build up of soil populations of $P$. cactorum (25) and $P$. syringae in apple orchards (24) and should be considered similar with $P$. kernoviae.

$P$. kernoviae produces caducous sporangia that are readily dislodged from infected tissues during rain, allowing spread to nearby hosts. It is significant that $P$. kernoviae produced amounts of sporangia per square centimeter of leaf tissue on all of the tested leaf material similar to or more than the other indigenous Phytophthora spp. (Table 2). These results have implications on the possible dissemination of this species. Although no studies have been completed to examine the distance of dispersal of $P$. kernoviae sporangia specifically, it is unlikely that it is much different from other Phytophthora spp. with caducous sporangia. Short-range dispersal up to $70 \mathrm{~cm}$ through rain splash has been demonstrated with $P$. palmivora (22) and up to $3,000 \mathrm{~m}$ through aerial dispersal of $P$. infestans (51). Mascheretti et al. (31) concluded that $P$. ramorum could be dispersed to $1 \mathrm{~km}$ in the presence of strong winds and rain. Sporangia of species capable of long-distance dispersal, such as $P$. infestans, can dry before being airborne and still be viable (40), whereas species characterized by the movement of turgid sporangia have shorter ranges. However, generally, sporangia do not survive under conditions of long-distance dispersal because sporangia viability is decreased under dry conditions (35). Based upon the limited number of hosts tested in this study, it appears that isolates potentially arriving from the United Kingdom might be capable of having a higher impact on dispersal based upon the significantly higher numbers of sporangia produced on three of the four hosts. Although it is unlikely that $P$. kernoviae will arrive in the United States through dispersal of sporangia, it is important to know whether sporangia are produced and in what relative quantity as secondary inoculum on host leaves for dispersal within a certain area.

It was not surprising that low numbers of sporangia were collected from any of the hosts inoculated with $P$. syringae. Although attempts were made to release sporangia from the leaves by scraping them, the sporangia formed may not have been completely dislodged because $P$. syringae sporangia are noncaducous, in contrast to those of $P$. kernoviae and P. cactorum. Harris (24) noted quick development of $P$. syringae on infected apple leaves but did not postulate on the impact of this on secondary spread. Recovery of Phytophthora spp. was near $100 \%$ from the inoculated leaf disks used to determine sporangia production. As noted, some of the leaf disks that produced sporangia were asymptomatic. This confirms the observation by Denman et al. (12), who first reported that infected tissue could be asymptomatic but still support sporulation. This is problematic for regulatory agencies and the nursery industry that rely on symptoms when scouting for infected plant material.

Results in this study will be of interest to government regulators. Currently, P. kernoviae is not present in the United States. One of the strategies to control plant diseases is exclusion (28). Two points can be made from this data regarding exclusion. First, the most aggressive isolates will most likely originate from the United Kingdom.

Table 2. Mean number of sporangia ( \pm standard error of the mean) collected per square centimeter of leaf tissue at 1 week after inoculation with different Phytophthora spp. zoospores ${ }^{\mathrm{y}}$

\begin{tabular}{|c|c|c|c|c|c|}
\hline Species & Isolatez $^{z}$ & Rhododendron Cunningham's White & Kalmia latifolia & Magnolia stellata & Liriodendron tulipifera \\
\hline P. kernoviae & UK & $431 \pm 61 \mathrm{a}$ & $98 \pm 15 a$ & $832 \pm 86 a$ & $521 \pm 85 a$ \\
\hline P. kernoviae & $\mathrm{NZ}$ & $570 \pm 102 a$ & $57 \pm 10 b$ & $138 \pm 21 b$ & $57 \pm 10 b$ \\
\hline P. cactorum & Pcac1 & $453 \pm 143 \mathrm{a}$ & $15 \pm 8 \mathrm{c}$ & $6 \pm 3 b$ & $13 \pm 4 b$ \\
\hline P. cactorum & 311 & $112 \pm 36 b$ & $19 \pm 4 c$ & $78 \pm 42 b$ & $55 \pm 12 b$ \\
\hline P. syringae & 468 & $1 \pm 0.9 \mathrm{c}$ & $5 \pm 2 c$ & $10 \pm 5 b$ & $2 \pm 2 b$ \\
\hline P. syringae & 469 & $0 \pm 0.0 \mathrm{c}$ & $4 \pm 3 c$ & $1 \pm 1 b$ & $0 \pm 0 \mathrm{~b}$ \\
\hline
\end{tabular}

y Numbers followed by the same letter within a column are not significantly different $(P>0.05)$ according to Tukey's test.

z The P. kernoviae isolates UK and NZ consisted of combined data for CSL 2378 and CSL 2286 (U.K. isolates) and ICMP 15082 and ICMP 14761 (New Zealand isolates), respectively, because there was no statistical difference among those isolates for each geographical location.

Table 3. Mean number of oospores ( \pm standard error of the mean) observed per $\mathrm{cm}^{2}$ leaf tissue after 2 weeks from inoculation with different Phytophthora spp. zoospores ${ }^{y}$

\begin{tabular}{lccccc}
\hline Species & Isolate $^{\mathbf{z}}$ & Rhododendron Cunningham's White & Kalmia latifolia & Magnolia stellata & Liriodendron tulipifera \\
\hline P. kernoviae & $\mathrm{UK}$ & $1464 \pm 261 \mathrm{c}$ & $0 \pm 0 \mathrm{~b}$ & $531 \pm 101 \mathrm{~cd}$ & $6589 \pm 1916 \mathrm{ab}$ \\
P. kernoviae & $\mathrm{NZ}$ & $3912 \pm 633 \mathrm{~b}$ & $11 \pm 10 \mathrm{~b}$ & $1834 \pm 252 \mathrm{~cd}$ & $10,162 \pm 2287 \mathrm{a}$ \\
$P$. cactorum & $\mathrm{Pcac} 1$ & $14,497 \pm 926 \mathrm{a}$ & $758 \pm 322 \mathrm{a}$ & $7801 \pm 1689 \mathrm{~b}$ & $7942 \pm 707 \mathrm{a}$ \\
P. cactorum & 311 & $3328 \pm 666 \mathrm{~b}$ & $426 \pm 137 \mathrm{a}$ & $10,467 \pm 1213 \mathrm{a}$ & $7375 \pm 4468 \mathrm{ab}$ \\
P. syringae & 468 & $4 \pm 2 \mathrm{~d}$ & $0 \pm 0 \mathrm{~b}$ & $39 \pm 15 \mathrm{~d}$ & $537 \pm 236 \mathrm{~b}$ \\
$P$. syringae & 469 & $2145 \pm 542 \mathrm{bc}$ & $4 \pm 3 \mathrm{~b}$ & $2285 \pm 363 \mathrm{c}$ & $5398 \pm 1014 \mathrm{ab}$ \\
\hline
\end{tabular}

y Numbers followed by the same letter within a column are not significantly different $(P>0.05)$ according to Tukey's test.

z The $P$. kernoviae isolates UK and NZ consisted of combined data for CSL 2378 and CSL 2286 (U.K. isolates) and ICMP 15082 and ICMP 14761 (New Zealand isolates), respectively, because there was no statistical difference among those isolates for each geographical location. 
Second, isolates from New Zealand may be introduced from plant material where the symptoms are not so obvious and less likely to be detected but still with the potential to infect new hosts. Some symptoms on the host plants tested in this study were not so obvious, especially the cherimoya leaves, but $P$. kernoviae could still be isolated from surface-sterilized tissue. This highlights the need for a precise test that can quickly process samples at the point of entry.

Finally, this information has implications in host range studies and the potential for $P$. kernoviae to spread. The results emphasize the need to use a variety of different isolates from different regions to screen host material for susceptibility to get accurate results of their susceptibility. Original host material and geographical origin was important in screening $P$. capsici host plants for resistance (21). Isolates from both the United Kingdom and New Zealand should be utilized in such tests whenever possible to get a more accurate data set. More susceptibility studies on different hosts need to be conducted to get an accurate view of what impact this pathogen may have on various ecosystems. Fichtner et al. (18) has made the first attempt of determining the susceptibility of two native North American Rhododendron spp. but this was on detached leaves, which do not always give the same results as whole-plant inoculations (47). Determining the susceptibility of key native North American tree and understory plant species and important ornamental plant species is one of the high research priorities listed in the United States Department of Agriculture's Recovery Plan for P. kernoviae (1).

\section{Acknowledgments}

I thank P. Tooley (United States Department of Agriculture-Agricultural Research Service, Fort Detrick, MD), T. Ramsfield (Canadian Forest Service, Edmonton, Alberta, formerly of Scion, New Zealand), P. Beales (Fera, York, United Kingdom), K. Hughes (Fera, York, United Kingdom), and M. Coffey (University of California, Riverside) for supplying the Phytophthora spp. isolates; S. Van Der Karr (Pinehill Ranch, Carpinteria, CA) and B. Faber (Ventura-University of California Cooperative Extension) for their generous gift of the cherimoya seed; and T. Lee, J. Beaulieu, and S. Dodge for their help in collecting data.

\section{Literature Cited}

1. Benson, M., Ivors, K., Koch, F., Fichtner, E., Garbelotto, M., Rizzo, D., Tjosvold, S., Hansen, E., Parke, J., Hong, C., Chastagner, G., Jeffers, S., Woodward-Williams, J., Kim, S. W., Britton, K., DeNitto, G., Frankel, S., Micales, J., Grunwald, N., Martin, F., Shishkoff, N., Smith, K., Tooley, P., Widmer, T., Bulluck, R., Burnett, G., Ferguson, L., Fowler, G., Garrett, L., Jones, J., Magarey, R., Randall-Schadel, B., Cardwell, K., Draper, M., and Chand-Goya, T. 2010. Recovery plan for Phytophthora kernoviae, cause of bleeding trunk cankers, leaf blight and stem dieback in trees and shrubs. U.S. Dep. Agric. Gov. Publ. Rep. http://www.ars.usda.gov/SP2UserFiles/ Place/00000000/opmp/P.\%20kernoviae\%2081100.pdf.

2. Brasier, C. M. 2008. Phytophthora ramorum $+P$. kernoviae $=$ international biosecurity failure. Pages 133-139 in: Proc. Sudden Oak Death Third Sci. Symp. S. J. Frankel, J. T. Kliejunas, and K. M. Palmieri, tech. coords. Gen. Tech. Rep. PSW-GTR-214, Pac. Southwest Res. Stn. For. Serv. U.S. Dep. Agric. Albany, CA.

3. Brasier, C. M. 2008. The biosecurity threat to the UK and global environment from international trade in plants. Plant Pathol. 57:792-808.

4. Brasier, C. M., Beales, P. A., Kirk, S. A., Denman, S., and Rose, J. 2005. Phytophthora kernoviae sp. nov., an invasive pathogen causing bleeding stem lesions on forest trees and foliar necrosis of ornamentals in the UK. Mycol. Res. 109:853-859.

5. Brasier, C. M., Kirk, S., and Rose, J. 2006. Differences in phenotypic stability and adaptive variation between the main European and American lineages of Phytophthora ramorum. Pages 166-173 in: Progress in Research on Phytophthora Diseases of Forest Trees. Proc. Third Int. IUFRO Working PartyS07.02.09, Freising, Germany. C. M. Brasier, T. Jung, and W. Oßwald, eds. Forest Research, Farnham, Surrey.

6. Brown, A., Brasier, C., and Webber, J. 2006. Aetiology and distribution of Phytophthora kernoviae and P. ramorum stem lesions on European beech in southwest England. Pages 139-141 in: Progress in Research on Phytophthora Diseases of Forest Trees. Proc. Third Int. IUFRO Working PartyS07.02.09, Freising, Germany. C. M. Brasier, T. Jung, and W. Oßwald, eds. Forest Research, Farnham, Surrey.

7. Cobb, R. C., Meentemeyer, R. K., and Rizzo, D. M. 2010. Apparent competition in canopy trees determined by pathogen transmission rather than susceptibility. Ecology 91:327-333.

8. Cushman, J. H., Cooper, M., Meentemeyer, R. K., and Benson, S. 2008. Human activity and the spread of Phytophthora ramorum. Pages 179-180 in: Proc. Sudden Oak Death Third Sci. Symp. S. J. Frankel, J. T. Kliejunas, and K. M. Palmieri, tech. coords. Gen. Tech. Rep. PSW-GTR-214, Pac. Southwest Res. Stn. For. Serv. U.S. Dep. Agric. Albany, CA.

9. Davidson, J. M., Wickland, A. C., Patterson, H., Falk, K., and Rizzo, D. M. 2005. Transmission of Phytophthora ramorum in mixed-evergreen forests of California. Phytopathology 95:587-596.

10. Defra. 2008. Consultation on future management of risks from Phytophthora ramorum and Phytophthora kernoviae. Department for Environment, Food and Rural Affairs. London. http://forestphytophthoras.org/sites/default/files/ educational_materials/DEFRA\%25202008\%2520Risk\%2520management.pdf

11. Denman, S., Kirk, S. A., Brasier, C. M., and Webber, J. F. 2005. In vitro leaf inoculation studies as an indication of tree foliage susceptibility to Phytophthora ramorum in the UK. Plant Pathol. 54:512-521.

12. Denman, S., Kirk, S. A., Moralejo, E., and Webber, J. F. 2009. Phytophthora ramorum and Phytophthora kernoviae on naturally infected asymptomatic foliage. Bull. OEPP/EPPO Bull. 39:105-111.

13. Denman, S., Kirk, S., Whybrow, A., Orton, E., and Webber, J. F. 2006 Phytophthora kernoviae and $P$. ramorum: host susceptibility and sporulation potential on foliage of susceptible trees. Bull. OEPP/EPPO Bull. 36:373-376.

14. Dudzinski, M. J., Old, K. M., and Gibbs, R. J. 1993. Pathogenic variability in Australian isolates of Phytophthora cinnamomi. Aust. J. Bot. 41: 721-732.

15. Elliott, M., Sumampong, G., Vara, A., Shamoun, S. F., Jumas, D., Masri, S., and Grünwald, N. J. 2011. Phenotypic differences among three clonal lineages of Phytophthora ramorum. For. Pathol. 41:7-14.

16. Erwin, D. C., and Ribeiro, O. K. 1996. Phytophthora Diseases Worldwide. American Phytopathological Society, St. Paul, MN.

17. Fera. 2010. Fera list of natural hosts of Phytophthora kernoviae with symptoms. The Food and Environment Research Agency, London. http:// fera.defra.gov.uk/plants/plantHealth/pestsDiseases/phytophthora/documents/ pKernoviaeHost.pdf.

18. Fichtner, E. J., Rizzo, D. M., Kirk, S. A., and Webber, J. F. 2012. Infectivity and sporulation potential of Phytophthora kernoviae to select North American native plants. Plant Pathol. 61:224-233.

19. Flier, W. G., and Turkensteen, L. J. 1999. Foliar aggressiveness of Phytophthora infestans in three potato growing regions in the Netherlands. Eur. J. Plant Pathol. 105:381-388.

20. Goss, E. M., Tabima, J. F., Cooke, D. E. L., Restrepo, S., Fry, W. E., Forbes G. A., Fieland, V. J., Cardenas, M., and Grünwald, N. J. 2014. The Irish potato famine pathogen Phytophthora infestans originated in Central Mexico rather than the Andes. Proc. Natl. Acad. Sci. USA 111:8791-8796.

21. Granke, L. L., Quesada-Ocampo, L. M., and Hausbeck, M. K. 2012. Differences in virulence of Phytophthora capsici isolates from a worldwide collection on host fruits. Eur. J. Plant Pathol. 132:281-296.

22. Gregory, P. H., Griffin, M. J., and Maddison, M. R. 1984. Cocoa black pod: a reinterpretation. Cocoa Grow. Bull. 35:5-22.

23. Grönberg, L. M., Andersson, B., and Yuen, J. 2012. Can weed hosts increase aggressiveness of Phytophthora infestans on potato? Phytopathology 102: 429-433.

24. Harris, D. C. 1985. The colonization of fallen apple leaves by Phytophthora syringae in relation to inoculum levels in orchard soil. Ann. Appl. Biol. 107:179-188.

25. Harris, D. C. 1989. The significance of apple tree tissues for regeneration of Phytophthora cactorum in apple orchards. J. Hortic. Sci. 64:389-393.

26. Holmes, K. A., Evans, H. C., Wayne, S., and Smith, J. 2003. Irvingia, a forest host of the cocoa black pod pathogen, Phytophthora megakarya, in Cameroon. Plant Pathol. 52:486-490.

27. Hüberli, D., and Garbelotto, M. 2012. Phytophthora ramorum is a generalist plant pathogen with differences in virulence between isolates from infectious and dead-end hosts. For. Pathol. 42:8-13.

28. Kahn, R. P. 1991. Exclusion as a plant disease control strategy. Annu. Rev Phytopathol. 29:219-246.

29. Linderman, R. G., Davis, E. A., and Marlow, J. L. 2006. Response of selected nursery crop plants to inoculation with isolates of Phytophthora ramorum and other Phytophthora species. HortTechnology 16:216-224.

30. Linderman, R. G., de Sá, P. B., and Davis, E. A. 2007. Comparative susceptibility of plants native to the Appalachian range of the United States to inoculation with Phytophthora ramorum. Online publication. Plant Health Prog. 10.1094/PHP-2007-0917-01-RS.

31. Mascheretti, S., Croucher, P. J., Vettraino, A., Prospero, S., and Garbelotto, M. 2008. Reconstruction of the sudden oak death epidemic in California through microsatellite analysis of the pathogen Phytophthora ramorum. Mol. Ecol. 17: 2755-2768.

32. Miller, J. S., Johnson, D. A., and Hamm, P. B. 1998. Aggressiveness of isolates of Phytophthora infestans from the Columbia Basin of Washington and Oregon. Phytopathology 88:190-197.

33. Parke, J. L., and Lewis, S. 2008. Sudden oak death and ramorum blight. Online publication. Plant Health Instruct.

34. Ramsfield, T. D., Dick, M. A., Beever, R. E., Horner, I. J., McAlonan, M. J. and Hill, C. F. 2009. Phytophthora kernoviae in New Zealand. Pages 47-53 in: Phytophthoras in Forests and Natural Ecosystems. Proc. Fourth Meet. Int Union For. Res. Organ. (IUFRO) Working Party, Monterey, CA. Gen. 
Tech. Rep. PSW-GTR-221. E. M. Goheen and S. J. Frankel, eds. U.S. Dep. Agric. For. Serv. Pac. Southwest Res. Stn. Albany, CA.

35. Ristaino, J. B., and Gumpertz, M. C. 2000. New frontiers in the study of dispersal and spatial analysis of epidemics cause by species in the genus Phytophthora. Annu. Rev. Phytopathol. 38:541-576.

36. Rooney-Latham, S., Honeycutt, E., Ochoa, J., Grünwald, N. J., and Blomquist, C. L. 2013. First report of camphor tree (Cinnamomum camphora) as a host of Phytophthora ramorum. Plant Dis. 97:1377.

37. Shaner, G., Stromberg, E. L., Lacy, G. H., Barker, K. R., and Pirone, T. P. 1992. Nomenclature and concepts of pathogenicity and virulence. Annu. Rev. Phytopathol. 30:47-66.

38. Shishkoff, N. 2006. Susceptibility of Camellia to Phytophthora ramorum. Online publication. Plant Health Prog. 10.1094/PHP-2006-0315-01-RS.

39. Spiglazova, S., Kuznetsova, M., Smetanina, T., and Filippov, A. 2012. Changes in Phytophthora infestans aggressiveness as a result of repeated introductions on different potato cultivars. PPO Spec. Rep. 15:225-228.

40. Sunseri, M. A., Johnson, D. A., and Dasgupta, N. 2002. Survival of detached sporangia of Phytophthora infestans exposed to ambient, relatively dry atmospheric conditions. Am. J. Potato Res. 79:443-50.

41. Surico, G. 2013. The concepts of plant pathogenicity, virulence/avirulence and effector proteins by a teacher of plant pathology. Phytopathol. Mediterr. 52: 399-417.

42. Tooley, P. W., and Browning, M. 2009. Susceptibility to Phytophthora ramorum and inoculum production potential of some common Eastern forest understory plant species. Plant Dis. 93:249-256.
43. Tooley, P. W., Kyde, K. L., and Englander, L. 2004. Susceptibility of selected Ericaceous ornamental host species to Phytophthora ramorum. Plant Dis. 88 993-999.

44. Webber, J., and Rose, J. 2008. Dissemination of aerial and soilborne Phytophthore by human vectors. Pages 195-198 in: Proc. Sudden Oak Death Third Sci. Symp. S. J. Frankel, J. T. Kliejunas, and K. M. Palmieri, tech. coords. Gen. Tech. Rep. PSW-GTR-214, Pac. Southwest Res. Stn. For. Serv. U.S. Dep. Agric. Albany, CA.

45. Widmer, T. L. 2010. Differentiating Phytophthora ramorum from $P$ kernoviae from other species isolated from foliage of rhododendrons. Online publication. Plant Health Prog. 10.1094/PHP-2010-0317-01-RS.

46. Widmer, T. L. 2010. Phytophthora kernoviae oospore maturity, germination, and infection. Fungal Biol. 114:661-668.

47. Widmer, T. L. 2010. Susceptibility of Viburnum species and cultivars to Phytophthora ramorum. J. Environ. Hortic. 28:197-202.

48. Widmer, T. L. 2011. Sporulation potential of Phytophthora kernoviae compared to. P. syringae and P. cactorum on selected hosts. (Abstr.) Phytopathology 101:S191.

49. Yin, J., Jackson, K. L., Candole, B. L., Csinos, A. S., Langston, D. B., and Ji, P. 2012. Aggressiveness and diversity of Phytophthora capsici on vegetable crops in Georgia. Ann. Appl. Biol. 160:191-200.

50. Zentmyer, G. A. 1977. Origin of Phytophthora cinnamomi: Evidence that it is not an indigenous fungus in the Americas. Phytopathology 67:1373-1377.

51. Zwankhuizen, M. J., Govers, F., and Zadoks, J. C. 1998. Development of potato late blight epidemics: Disease foci, disease gradients, and infection sources. Phytopathology 88:754-763. 